\title{
Gender Equality and Economic Growth Toward Fulfillment of Sustainable Development Goals
}

\author{
Vinsensia P Anggraeni ${ }^{1}$, Nurul Bariyah ${ }^{1 *}$ iD, Sri Kurniawati ${ }^{1}$ \\ ${ }^{1}$ Department of Economics and Development Studies, Faculty of Economics and Business, Universitas \\ Tanjungpura, Pontianak, Kalimantan Barat, Indonesia
}

\section{ARTICLE INFO}

Article History:

Received: July 14, 2021

Revision: January 23, 2022

Accepted: January 26, 2022

Keywords:

Gender

Growth

Life Expectancy

Mean Years of Schooling

Corresponding Author

E-mail:

nurul.bariyah@ekonomi.untan.ac.id

\begin{abstract}
In implementing the 2030 Agenda for the Sustainable Development Goals (SDGs), gender equality is fundamental to realizing the promises of sustainability, peace, and human progress. In 2020, females made up $49.42 \%$ of Indonesia's total population, while at the same time, Indonesia's score on the Gender Development Index was lower than the world's average GDI score. This study aims to analyze the effect of gender equality on economic growth in Indonesia in 20102019. In this study, a descriptive quantitative analysis approach was used, with the research object being the 33 provinces of Indonesia. The model used in this study is a multiple regression equation made to handle panel data. The results showed that Women's Life Expectancy had a negative and significant effect on economic growth. In contrast, Women's Average Length of Schooling has a negative and significant effect on economic growth. The study results revealed that improving the quality of women's human resources as measured by education and health and participation rates is a necessary but not sufficient factor in driving overall economic growth. It needs to be accompanied by proper policies that favor women regarding good job opportunities, a safe work environment, and decent wages.
\end{abstract}

\section{INTRODUCTION}

Sustainable Development Goals (SDGs) are development agreements that encourage sustainable development based upon the principle of human rights and equality to promote social, economic, and environmental development, one of which is gender equality. Currently, the world views gender equality as essential in fostering growth and achieving prosperity. It is hoped that the empowerment of women and girls is carried out optimally and that there are no role limits that will hinder women from developing. According to Arif et al. (2021), Bustelo et al. (2019), and Tejada et al. (2021), policies to increase the productivities of the labor force will benefit development in the region.
Global Gender Gap Index Data puts Indonesia in 85th place out of 153 countries, with a score of 0.70 , while Iceland at the top has a score of 0.877 . According to the Human Development Report (2019) data and the Gender Development Index in 2018, Indonesia's GDI score is 0.937 , still below the Global GDI average of 0.941 . Although not too far off, this figure indicates that Indonesia still needs to increase its efforts in terms of gender development to reach and exceed the global average GDI figure. The issue of gender gaining ground in the mainstream consciousness in Indonesia is reflected in the vision of national development through the elimination of gender discrimination. The 2015-2019 Midterm Development Plan (RPJMN) includes development targets from the 
female gender's perspective, such as improving women's quality of life, increasing women's impact in development, integrating the female gender's views at all stages of the development process, as well as strengthening female gender empowerment institutions, both at the central and regional levels (Dhewy, 2017). This makes more sense since 49 . Forty-two percent of Indonesia's population consists of women.

Mill (2018); and Ren (2020) stated that a population tends towards stability and must develop culturally, socially, morally, and economically higher than it used to be. In other words, an upward trend is assumed to be the norm in how a population develops over time. In principle, it followed Malthus' theory, with the idea that population growth - if not controlledwill eliminate the results obtained from economic development. In other words, population growth must be paired with lockstep economic growth. Bhuiyan et al. (2017); and Tarmidi et al. (2021) assume that investment in human resource development can improve the quality of human capital. Lewis's theory suggests that excess labor is an opportunity, not a problem. Extra workers in one sector will contribute to output growth and the supply of workers in other sectors.

According to the Central Agency of Statistics (BPS), the term "gender" is used to describe the innate differences in the roles of women and men as God's creation. Gender is the differentiation of roles, positions, responsibilities, and division of labor between men and women in a community based on the nature of women and men who are considered appropriate according to the community's ms, customs, beliefs, or habits of Women as human resources and as citizens have the same rights and obligations under the law and the same opportunities as men in various fields.

Women's Life Expectancy is considered capable of representing the women's health sector. If a woman's health is well, they can be highly productive and can be relied on to increase the economic growth of a country or region. H1: The variable of women's life expectancy positively affects economic growth. Research by Sari et al. (2019) demonstrates that an increase in women's life expectancy - which is projected by the rise in the life expectancy ratio-positively affects regional income.

Furthermore, research by Padang et al. (2019) shows that the life expectancy ratio has a negative and significant effect on regional income per capita. Rahmawati \& Hidayah (2020) showed that the life expectancy ratio also has a positive and significant impact on economic growth. Research by Mandal et al. (2018); and Khan et al. (2017) demonstrated that equality in the health sector would increase economic growth. A study by Awan \& Yaqoob (2019) found that female life expectancy and male life expectancy positively affect economic growth.

By increasing the level of education and eliminating gender discrimination in education, more space is freed up for women to play more roles in development and become policymakers in other fields such as economics, social, and politics (Kong et al., 2020). H2: The variable average length of school for women positively affects economic growth. According to Sari et al. (2019), the Average Length of School Ratio positively affects the gross regional domestic product (GRDP); an increase in the Average Length of School Ratio will increase the GRDP value. Research by Padang et al. (2019) found that the Average Length of School Ratio positively affected per capita GRDP. A study by Rahmawati \& Hidayah (2020) found that the Average Length of School Ratio positively affected increasing economic growth. Evans et al. (2021) found that gender equality in education positively affects per capita income. Research by Altuzarra et al. (2021) shows that equality in education will increase economic growth. According to a study conducted by Awan \& Yaqoob (2019), female education negatively affects GDP, but male education has a positive effect on 
GDP. Research conducted by Rizal \& Sholehuddin (2019) found that male education positively affected productivity, while female education in steady conditions had a positive effect on productivity levels. The results found in Dao et al.'s (2020) research show that the gender gap in education significantly reduces economic growth.

Huruta et al. (2019) found that the structure of the female workforce has a generally low level of education. This explains why there are still many women who work in the informal sector. Women working in this sector are not given legal protection guarantees, inadequate welfare guarantees, poor working conditions, and low incomes. Technological developments also easily marginalized women who work in the informal sector. H3: The variable of women's labor force participation rate positively affects economic growth. Research by Sari et al. (2019) found that the labor force participation ratio hurt GRDP, meaning that an increase in the female labor force participation ratio impacted reducing GRDP.

Furthermore, Rahmawati \& Hidayah (2020) found that increasing the labor force participation ratio was not enough to encourage economic growth. According to Awan \& Yaqoob (2019) research, female and male labor force participation is positively related to GDP growth. The results found in the study by Agénor et al. (2021) are that the gender gap in employment significantly reduces economic growth. The previous research conducted by Hatano (2021) stated that gender equality in the level of political and economic participation, in the short term, will have an impact on decreasing economic growth.

Based on the empirical gap discussed in the previous part, the author chose three variables that are considered capable of representing three sectors, namely:

1) The life expectancy of women represents the health sector.

2) The average length of schooling for women represents the education sector.
3) The labor force participation rate of women represents the employment sector.

There are three research questions in this study:

1) Does the life expectancy of women affect economic Growth in Indonesia?

2) Does the average length of schooling for women affect economic Growth in Indonesia?

3) Does the labor force participation rate of women in the Indonesian market affects economic growth in Indonesia?

From these questions, the purpose of this study can be summarized as such:

1) To calculate and analyze the effect of women's life expectancy on economic growth in Indonesia.

2) To calculate and analyze the effect of women's average length of schooling on economic Growth in Indonesia.

3) To calculate and analyze the effect of women's labor force participation rates on economic growth in Indonesia.

The conceptual framework of the research can be seen in the following chart.

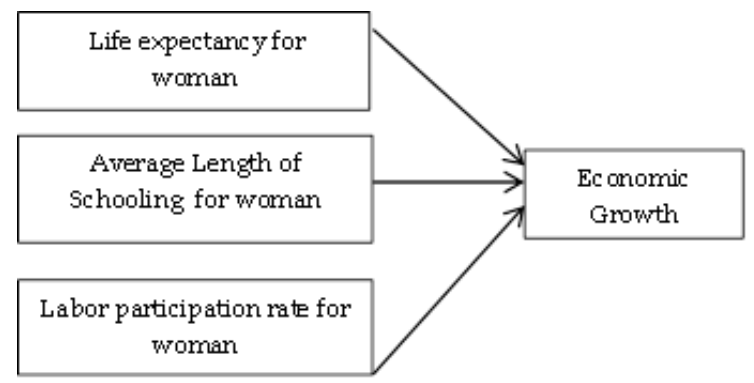

Figure 1. Conceptual framework of the research

The following part highlight the significance of the study. Previous studies on the relationship between gender equality and welfare gave mixed results. This raises doubts about whether the relationship between gender equality and economic progress can be considered a valid factor in future studies. This study seeks to provide new evidence regarding the relationship 
between women's quality of life as measured by indicators of health, education, and participation rates with economic growth. Furthermore, this study attempts to discuss the transmission mechanism by which independent variables, namely: women's life expectancy, women's length of schooling, and women's labor participation rate, are connected to economic growth so that it can be used as a basis for formulating appropriate policies for the achievement of women's welfare and in turn achieving one of the SDG goals.

\section{RESEARCH METHOD}

The approach used in this research was the descriptive quantitative analysis one. The object of study was the 33 provinces in Indonesia, ranging from 2010to 2019. The data consists of the Life Expectancy of Women from 33 Provinces in Indonesia. Average Length of Schooling for a woman from 33 Provinces in Indonesia. Women's Labor Force Participation Rate from 33 Provinces in Indonesia and Economic Growth of 33 Provinces in Indonesia. The type of research data is secondary data or processed data collected from the Indonesian Central Agency of Statistics (BPS) and official publications of institutions related to the data mentioned above. Analysis of the effect of life expectancy for women, average years of schooling for women, and labor force participation rate for women toward economic growth using panel data regression method. Panel data combines cross-sectional data and time-series data
Kuncoro (, 2014). There are three models in panel data regression: the standard effect model, fixed effect, and random effect. The Chow and Hausman tests were carried out to determine the appropriate panel data model.

The multiple regression equation for panel data in this study is.

$$
\begin{gathered}
\text { PEit }=\beta_{0}+\beta_{1} i t A H H P i t+\beta_{2} i t R T L S P i t \\
+\beta_{3} i t T P A K P i t+\varepsilon i t
\end{gathered}
$$

Where:

i: number of observations (34 provinces)

$\mathrm{t}$ : time (2010 - 2019)

PE: Economic Growth

$\beta_{\mathrm{o}}$ : Constant

AHHP: Life Expectancy for woman

RLSP: Average year of schooling for

woman

TPAKP: Labor force participation rate for a woman

$\beta 1,2,3$ : regression coefficient

$\varepsilon$ : error term

\section{RESULTS AND DISCUSSION}

This study examines the effect of gender inequality on economic growth in Indonesia from 2010 to 2019 using a panel data regression model. The data used in this analysis is panel data from 33 Provinces over ten years with 330 observations. The variables used are Economic Growth as the dependent variable while Women's Life Expectancy, Average Length of Schooling for Women, and Women's Labor Force Participation Rate as the independent variable.

Table 1. Stationarity test at level

\begin{tabular}{cc}
\hline Variable & Probability \\
\hline PE & 0.0000 \\
AHHP & 0.0245 \\
RLSP & 0.0037 \\
TPAKP & 0.0000 \\
\hline
\end{tabular}

The data requirements can be processed by panel data regression, and the data must be stationary. The table above shows that the variable data is static; this is indicated by the probability value of each variable, which is below 0.05 . 
Table 2. Chow test and Hausman test

\begin{tabular}{cccc}
\hline Test Tool & Prob & Sig & Decision \\
\hline Chow & 0.00 & 0.05 & Fixed Effect \\
Hausman & 0.05 & 0.05 & Fixed Effect \\
\hline
\end{tabular}

Table 2 above shows that the Chow and Hausman test's probability value is less than a significant level of 0.05 , which means that the fixed effect model is the best. Based on the selected regression model, namely the Fixed Effect model, the constant and coefficient values are found, which will be described in table 3 below.

Table 3. Multiple regression - fixed effect model

\begin{tabular}{ccc}
\hline Variable & Coefficient & Probability \\
\hline Constant & 49.28825 & 0.0000 \\
RAHH & -0.556757 & 0.0023 \\
RRLS & -0.450551 & 0.0261 \\
RTPAK & -0.011973 & 0.2697 \\
\hline
\end{tabular}

Regression equation:

$P E=49.28825-0.556757 A H H P_{i t}-0.450551 R L S P_{i t}+0.011973 T P A K P_{i t}+\varepsilon_{i t}$

From the above equation, it can be explained as follows: The constant of 49.28825 indicates that if all the independent variables, namely the life expectancy of women, the average length of schooling for women, and women's labor force participation ratio are 0 , the economic growth is $=49.28825$ units. This figure is relatively high for an economic growth rate. According to Gujarati (2015), the intercept value is not always meaningful because often, the range of values of the independent variable does not include zero as one of the observed values. In the case of the equation in the study where the independent variables are female life expectancy, the average female length of schooling, and female LFPR, which will never be worth 0 . Then the interpretation of the intercept or constant does not describe the actual situation and may be ignored.

The regression coefficient value of the female life expectancy (AHHP) variable is -0.556757 , which means that when there is an increase in the female life expectancy variable by 1 unit, there will be a decrease in economic Growth (PE) of -0.556757 units assuming the other independent variables remain constant (ceteris paribus).

The regression coefficient value of the Average Length of Schooling Ratio (RLSP) variable is -0.450551 , which means that when there is an increase in the average female length of schooling by 1 unit, there will be a decrease in economic Growth (PE) of -0.40551 units assuming independent variables. Others are fixed (ceteris paribus).

The coefficient value of the female labor force participation rate (TPAKP) variable is -0.011973 , indicating that when there is an increase in the female labor force participation rate variable by 1 unit, there will be an increase in economic Growth (PE) of -0.011973 units assuming the other variables remain constant (ceteris paribus).

Table 4. T-test

\begin{tabular}{ccc}
\hline Var & t-Stat & Probability \\
\hline AHHP & $-3.079^{*}$ & 0.00 \\
RLSP & $-2.236^{*}$ & 0.02 \\
TPAKP & -1.106 & 0.27
\end{tabular}

\footnotetext{
*Significance
} 
Based on the estimation results of the model presented in table 4 , the results can be explained as follows: The AHHP variable shows the direction of the relationship, which is harmful and significant. This means that women's life expectancy substantially affects Indonesia's economic growth. The RLSP variable shows the direction of the relationship, which is harmful and significant. This shows that the Average Length of Schooling for Women substantially affects Indonesia's Economic Growth. The TPAKP variable shows a positive and insignificant relationship. It also shows that the Female Labor Force Participation Rate has no significant effect on Indonesia's Economic Growth.

Table 5. F Test

\begin{tabular}{cc}
\hline F-statistik & 26.09 \\
Prob(F-statistik) & 0.00 \\
\hline
\end{tabular}

Based on Table 5 above, which shows the probability value of the F-statistical test of 0.00 , which is less than the significant level of 0.05, from these results, it can be concluded that women's life expectancy, women's average length of schooling, and labor force participation rates women influence Economic Growth in Indonesia.

\section{Life Expectancy for Woman and Economic Growth}

Seeing the negative coefficient value means that if the $\mathrm{AHH}$ of women increases, economic growth decreases. Life expectancy is closely related to infant mortality. The increased life expectancy indicates that the infant mortality rate is falling. Holyachi \& Kengnal (2017) stated that an increased infant mortality rate would reduce economic growth through a reduced workforce. So, on the other hand, if the infant mortality rate is low, the labor force will grow. This should have a positive effect on economic growth. However, considering the quality of Indonesian women's human resources, which are still considered lacking in terms of education and the availability of job opportunities, which causes the unemployment rate to remain high, the increased labor force will increase the unemployment rate and be unproductive. In Indonesia, the average length of schooling for women in 2019 was 7.89 years, and this figure shows that the average Indonesian woman in 2019 did not finish junior high school. This low level of education does not support the formation of quality female human resources, even if, on the other hand, public health improves. If the infant mortality rate is low, life expectancy increases. Still, it is not accompanied by guaranteed access to education and employment for women. Women will become less prosperous because it will be challenging to find work when they enter their productive age.

The dependency ratio is a ratio that shows the dependents borne by the productive population. The data shows that women dominate the effective age population; it can be seen from the total population aged 15 years and over, which is greater than men. Still, from the type of activity, far fewer women work than men who work. This is what causes women to become "burdens" or dependents. So, if the life expectancy of women increases which is not accompanied by the absorption of female workers, it will be a burden for development, coupled with the increase in population every year. Therefore, the government must be careful in making policies. Improving women's health can be very good for development and growth, if policies regarding fertility control such as the Family Planning program must be implemented correctly. The demographic bonus faced by Indonesia should be a potential resource for increasing national output or economic growth. However, according to UNDP (UNDP, 2019) in Yana (2019), there are considerable challenges in utilizing human resources, including. 
1. Public awareness of birth control

2. The quality of existing resources so that they can be competitive in the world of work and the international market

3. Education level that is not optimal and evenly distributed

4. Availability of job opportunities

These four challenges are significant to pay attention to so that the availability of the abundant productive age population, especially women, can be optimally empowered.

So, if the life expectancy of women increases which is not accompanied by the absorption of female workers, it will be a burden for development, coupled with the increase in population every year. According to Mill, an ideal country is a country where all people feel comfortable economically; not too large dependents can reflect this comfort because of the high independence of the population. Therefore, the government must be careful in making policies. Improving women's health can be very good for development and growth, if policies regarding fertility control such as the Family Planning program must be appropriately implemented. This is in line with Mill's theory which believes that population restrictions are essential. According to Mill, a good population is stable and developed morally and culturally.

Another important thing is the quality of human resources from women themselves. Controlled fertility and a high life expectancy must be accompanied by the quality of qualified female human resources, which will undoubtedly become women's capital to carry out productive activities, both work and entrepreneurship. The quality of skilled human resources must then be accompanied by the availability of job opportunities for women to become quality resources both physically and spiritually and can be relied on to increase economic growth.
Year of Schooling for woman and Economic Growth

The average length of schooling illustrates the high quality of education achieved by residents of a country. Basically, the higher the average number of years of education, the higher the level of instruction taken by the country's average population, and the higher the quality of human resources, which will affect both direct and indirect economic growth. However, the results of this study are not in line with the research hypothesis, namely, the average length of school has a positive effect on economic growth. This is very interesting because higher education for both women and men should increase economic growth through many things, including high productivity as employees and entrepreneurs, absorption of educated workers, and the export of skilled workers. However, this study shows that increasing the quality of human resources by increasing the average length of schooling for women will reduce economic growth. According to research conducted by Awan \& Yaqoob (2019), the negative relationship between women's education and economic growth is due to the main reason, namely fewer job opportunities for women, in other words, increasing the quality of women's education is useless and only wastes capital costs for education. If then their expertise is not used for work, or the educated female workforce is not absorbed. Wherever there are, the jobs available to women tend to be concentrated in low value-added sectors that do not require skills or higher levels of education. Gender differences in the division of labor can help explain why an increase in women's education leads to a lower increase in labor productivity than an increase in men's education.

Research conducted by Rizal \& Sholehuddin (2019) found that male education positively affected productivity, while female education in steady conditions had a positive impact on productivity levels. In less developed areas, only male education significantly affects productivity. This is because, in these areas, the average 
education level of women is so low that it cannot significantly affect productivity. Coupled with the possibility of employment opportunities for educated workers are fewer in less developed areas. As in the study conducted by Dao et al. (2020), which found that the effect of the gender gap in education for adults over 15 years of age on economic growth was significant in developing countries in the late 20th and early 21st centuries, this is because these regions is an area where educated women are very active in the labor market.

This does not mean that women's education is not essential, but that the average length of schooling for women must reach a limit that is considered sufficient to encourage economic growth, for example, the junior secondary level or junior high school level, namely nine years of education (9 years compulsory education government program), while The data shows that the average length of schooling for Indonesian women in 2019 is only 7.89 years, which means that they have not finished junior high school. Research by Amâncio \& Santos (2021) found that in developing or urban areas, women's education had a statistically significant effect. In urban Indonesia, women aged 15 years and over attend, on average, up to grade 1 of high school; meanwhile, in rural areas, the middle school is up to grade 6 of elementary school or 1 of junior high school (KPP \& PA Republik Indonesia, 2019a).

There are very few job opportunities for educated women in rural areas, so they migrate to urban areas. This causes a decrease in agricultural productivity in rural areas due to the movement of women workers from villages to cities Rizal \& Sholehuddin, 2019). But in the town, these immigrant women do not always immediately get better jobs because of the city's lack of job opportunities and firm competitiveness. The possible background of the lack of strong competitiveness in the city is partly because of education which, according to him, is relatively high compared to the average education of the people in the village, which is still below the intermediate education of the urban community. This can trigger an increase in unemployment and urban population density. Therefore, education for women is not enough if it only slightly exceeds the threshold but must be higher and accompanied by good soft skills.

One of the main factors causing women's poverty is the low level of education (Markoc, 2021). A high level of education with high competence will also make a person more productive in getting a job or entrepreneurship, undoubtedly increasing productivity and economic growth. The average length of schooling for women in Indonesia has not yet reached the threshold for a positive effect on economic growth. To make women's education a positive influence on economic growth, the government must consistently promote educational and training programs and assistance for women and men so that the average length of schooling can increase across all genders and have a positive impact on economic growth. Education (formal and non-formal) can play an essential role in reducing poverty in the long term, either indirectly through improving productivity and efficiency in general or directly through training the poor with the skills needed to increase their productivity and increase their productivity incomes Arsyad (2015). Women of productive age who do not finish school or choose to be homemakers can continue developing through informal education, which can be easily accessed today with advances in information technology. Solow and Swan argue that economic growth is a series of activities that originate from humans, capital accumulation, use of modern technology, and results or outputs. Solow emphasized the importance of technological progress in every production process to achieve sustainable economic growth Garza-Rodriguez et al. (2020).

Currently, many women are engaged in the informal sector, for example, online business. Data from Bank Indonesia (Departemen Internasional Bank Indonesia, 
2019), in 2018, the total micro, small, and medium enterprises 2018 reached 57.83 million, with more than $60 \%$ managed by women. The use of the internet for online business is starting to be widely used by women because it is more flexible to run their business from home without interfering with their responsibilities as housewives. Women's proficiency in using technology can make it easier for them to conduct electronic transactions and make their businesses more advanced, effective, and efficient. In the end, proficiency in using technology results in productive activities that generate income for women who double as housewives.

\section{Labor Force Participation Rate for woman and Economic Growth}

This study indicates that women's LFPR has a negative and insignificant effect on economic growth; it can be interpreted that if women's LFPR increases, economic growth decreases. Thus, these results are in line with the research hypothesis. According to Lewis's employment theory, excess labor is not a problem but an opportunity. An increase in women's LFPR will boost economic growth because these economically unproductive women in the labor force contribute to GDP. According to Solow's economic theory, the labor force is one of the main assets to encourage economic growth. An increase in the labor force must be accompanied by an increase in education to promote labor productivity, increasing economic growth. Of course, the increase in the quality and quantity of the workforce must be accompanied by employment opportunities.

The negative relationship between women's LFPR and economic growth can be explained by data showing that LFPR consists of a workforce where the labor force consists of people of working age (15 years and over) who work or have jobs but are temporarily unemployed and unemployed (KPP \& PA Republik Indonesia, 2020). The increase in LFPR indicated that women of working age decided to enter the labor market.
However, if the availability of job opportunities does not accompany the rise in women's LFPR, it will lead to unemployment. So, it could be that the increase in LFPR is an increase in the number of open unemployment, then the growth will increase the economic problem, namely unemployment.

Seen further from the publication data of Gender-Based Human Development (2020), formal female workers are 39.31\% while female informal workers are $60.69 \%$; therefore, women who work are dominated by informal sector jobs. This can be related to two things, firstly, the cultural burden in society that constructs women to be fully responsible in the domestic sphere, resulting in most women workers preferring to work in informal rather than formal jobs. Second, the wage/income of female workers is lower than that of male workers. Women informal workers are also more commonly found in quite risky jobs, for example, domestic workers, homeworkers, or family workers. Women who work in the informal sector also earn relatively low wages, do not receive social and legal protection, do not receive leave, pension funds, health insurance, and are vulnerable to unsafe conditions such as sexual harassment.

From the explanation above, the increase in the number of women's LFPR may reduce economic growth, firstly because of the addition of the workforce, which is not accompanied by the availability of employment opportunities, and secondly because of the inadequate quality of work for women, both in terms of the work environment, rights and protection of workers: work and wages. So, if the LFPR continues to increase, it will increase open unemployment and female workers who continue to be depressed because their results are not commensurate with their hard work. Women's LFPR will boost economic growth if the number of women workers with good quality human resources and good jobs and decent wages.

According to the Sakernas Survey 2018 by (Badan Pusat Statistik, 2018), the 
male workforce is higher than the female workforce at $82.69 \%$, while the female force is only $51.88 \%$. Around $61.80 \%$ of women are still working in the informal sector. The main employment opportunities are still in the agriculture, forestry, and fisheries sectors, $26.62 \%$, followed by wholesale and retail trade car and motorcycle repair and maintenance, then the retail industry. Next is the processing industry, which is $16.45 \%$. This data can be related to the fact that most women's jobs are agriculture, forestry, and fisheries, where these jobs tend to be carried out in rural areas. The low female LFPR, which is quite far from the male LFPR, can be caused by lack of information, gender discrimination in employment, high education costs, and a patriarchal culture that views women as fully responsible for the household. This limits the space for women to develop who should have the same rights as men. Many women work in the informal sector with low incomes, such as domestic workers or homeworkers. Casual sector workers are at risk of not getting legal aspects of labor protections such as minimum wages, severance pay, overtime pay, old-age insurance, health insurance, and so on. By not getting the legal aspects of employment protection mentioned above, informal workers can live in uncertainty, vulnerable to losing their jobs and income.

Women's awareness of the importance of taking a role in economic activities must be responded to by creating jobs, decent wages, and appropriate skills training for women. $43.43 \%$ of women 15 years and over who work only have elementary school graduates and below. This shows that almost half of women who work have low-quality human resources, which causes the average wage for women to be much lower than men is only Rp. 2.39 million rupiahs, while for men, 3.06 million rupiahs.

\section{CONCLUSION}

From the results of the research and discussion that has been described, it can be concluded that the life expectancy of women and the average length of schooling for women have a negative and significant effect on Indonesia's economic growth in 2010-2019, while the participation rate of the female workforce has a negative and insignificant impact on Indonesia's economic growth in 2010-2019.

Based on the results of research and discussions that have been carried out, several recommendations were put forward, including Through the Community Health Center (Pusat Kesehatan Masyarakat/Puskesmas), the government is expected to continue to control fertility through the Family Planning program by providing continuous information and counseling to the community to increase awareness of the importance of the agenda for the community, especially the lower-middleincome community. To increase the average number of years of schooling, the government must consistently promote programs and assistance in the education sector so that the poor can continue their education. Serious work on training or informal education programs that are appropriate and appropriate for the characteristics of women who have obligations in the household. Determination of gender-responsive policies or budgets based on accurate data to be well absorbed and felt by the community. Steps that can be taken to determine the right program and budget include identifying the problems faced by women from all groups, especially the poor, then setting priorities according to the group's interests, then proposing and determining programs/projects according to the mapping of the result. Needs, setting a budget for each program, and finally measuring the success of program implementation will have a tangible impact on the community. The government must ensure the availability of job opportunities for women, mainly formal jobs that can absorb educated workers and increase women's income. 


\section{REFERENCES LIST}

Agénor, P. R., Ozdemir, K. K., \& Pinto Moreira, E. (2021). Gender Gaps in the Labour Market and Economic Growth. Economica, 88(350). https://doi.org/10.1111/ecca.12363

Altuzarra, A., Gálvez-Gálvez, C., \& González-Flores, A. (2021). Is gender inequality a barrier to economic growth? A panel data analysis of developing countries. Sustainability (Switzerland), 13(1). https://doi.org/10.3390/su13010367

Amâncio, L., \& Santos, M. H. (2021). Gender equality and modernity in Portugal. An analysis on the obstacles to gender equality in highly qualified professions. Social Sciences, 10(5). https://doi.org/10.3390/socsci100501 62

Arif, M., Rosni, R., Rona Islami, Z., \& Rahmadi, M. T. (2021). The Analysis of the Impact of Working-Age Population on Indonesian Labour. Jurnal Geografi, 13(1). https://doi.org/10.24114/jg.v13i1.21 145

Arsyad, L. (2015). Ekonomi Pembangunan Lanjutan. In Ekonomi Pembangunan Berkelanjutan (Vol. 05, Issue 01).

Awan, A. G., \& Yaqoob, H. A. (2019). The Impact of Gender Inequality on Economic Growth in Pakistan. Global Journal of Management, Social Sciences, and Humanities, 5(4), 680698.

https://www.researchgate.net/publi cation/336989748_The_Impact_Of_Ge nder_Inequality_On_Economic_Grow th_In_Pakistan

Badan Pusat Statistik. (2018). Keadaan Angkatan Kerja di Indonesia per Agustus 2018. Bps Ri, 91(August).

Bhuiyan, M. Z. H., Uddin, M. M., Ahmad, A., \& Hoque, N. (2017). Does investment in human resource development affect financial performance? Empirical evidence from the banking sector of Bangladesh. IIUC Studies, 14(2). https://doi.org/10.3329/iiucs.v14i2.3
9879

Bustelo, M., Flabbi, L., Piras, C., \& Tejada, M. (2019). Female Labor Force Participation, Labor Market Dynamic, and Growth. Inter-American Development Bank, 1-36.

Dao, T. N., Dávila, J., \& Greulich, A. (2020). The Gender Gap in Education Investment and the Demographic Transition in Developing Countries: Theory and Evidence. SSRN Electronic Journal. https://doi.org/10.2139/ssrn.3509594

Departemen Internasional Bank Indonesia. (2019). Perkembangan Ekonomi Keuangan dan Kerja Sama Internasional - Edisi IV 2019 (IV). Bank Indonesia.

Dhewy, A. (2017). Gender Perspective as Formality: Feminist Policy Analysis toward RPJMN 2015-2019 and Strategic Plan of KPPPA 2015-2019. Jurnal Perempuan, 22(1).

Evans, D. K., Akmal, M., \& Jakiela, P. (2021). Gender gaps in education: The long view. IZA Journal of Development and Migration, 12(1). https://doi.org/10.2478/izajodm2021-0001

Garza-Rodriguez, J., Almeida-Velasco, N., Gonzalez-Morales, S., \& Leal-Ornelas, A. P. (2020). The Impact of Human Capital on Economic Growth: the Case of Mexico. Journal of the Knowledge Economy, 11(2). https://doi.org/10.1007/s13132-0180564-7

Gujarati, D. N. (2015). Ekonometrika Dasar Edisi Kelima Buku 1. In New York: The McGraw-Hill Companies, Inc.

Hatano, A. (2021). Toward Aligning with International Gender Goals? Analysis of the Gender Equality Landscape in Japan under the Lawson Women's Economic and Political Participation and Leadership. In Law and Development Review (Vol. 14, Issue 2). https://doi.org/10.1515/ldr-20210044

Holyachi, S., \& Kengnal, P. R. (2017). The Causal Relationship between Infant 
Mortality Rate, Health Expenditure and Economic Growth in India. International Journal of Public Health Research, 7(1).

Huruta, A. D., Sasongko, G., \& Sari, P. I. A. (2019). The Determinant of Female Worker's Income in Central Java. JIEP, 19(1).

https://doi.org/https://doi.org/10.2 0961/jiep.v19i1.25548

Jeníček, V. (2010). World Population Development, Transition. Agricultural Economics, 56(1). https://doi.org/10.17221/92/2009agricecon

Kabisch, N., Haase, D., \& Haase, A. (2012). Urban Population Development In Europe, 1991-2008: The Examples of Poland and the UK. International Journal of Urban and Regional Research, 36(6). https://doi.org/10.1111/j.14682427.2012.01114.x

Khan, H. U. R., Khan, A., Zaman, K., Nabi, A. A., Hishan, S. S., \& Islam, T. (2017). Gender Discrimination in Education, Health, and Labour Market: A Voice For Equality. Quality and Quantity, 51(5).

https://doi.org/10.1007/s11135-0160384-4

Kong, S., Carroll, K., Lundberg, D., Omura, P., \& Lepe, B. (2020). Reducing Gender Bias in STEM. MIT Science Policy Review, 1. https://doi.org/10.38105/spr.11kp61 qr0a

KPP \& PA Republik Indonesia. (2019). Pembangunan Manusia Berbasis Gender 2019. KPP \& PA Republik Indonesia.

https://www.kemenpppa.go.id/lib/ uploads/list/44ac0-pembangunanmanusia-berbasis-gender-2019.pdf

KPP \& PA Republik Indonesia. (2020). Pembangunan Manusia Berbasis Gender 2020. KPP \& PA Republik Indonesia.

https://www.kemenpppa.go.id/lib/ uploads/list/50a46-pembangunanmanusia-berbasis-gender-2020.pdf
Kuncoro, M. (2014). Metode Riset Untuk Bisnis Dan Ekonomi, Jakarta Erlangga (4th ed.). Erlangga.

Mandal, B., Batina, R. G., \& Chen, W. (2018). Do gender gaps in education and health affect economic growth? A cross-country study from 1975 to 2010. Health Economics (United Kingdom), 27(5). https://doi.org/10.1002/hec.3636

Markoc, I. (2021). Poverty and Difficulties in Participation of Urban Social Life: Young Women in Istanbul. Journal of International Women's Studies, 22(9).

Mill, J. S. (2018). Principles of Political Economy. In The Economics of Population.

https://doi.org/10.4324/97813512915 21-15

Padang, D. M., Anis, A., \& Ariusni. (2019). Analisis Pengaruh Kesetaraan Gender Terhadap Pertumbuhan Ekonomi di Sumatera Barat. Jurnal Kajian Ekonomi Dan Pembangunan, 1(3), 969-976.

https://doi.org/10.24036/jkep.v1i3.7 724

Rahmawati, F., \& Hidayah, M. H. (2020). Menelusur Relasi Indikator Indeks Pembangunan Gender Terhadap Pertumbuhan Ekonomi. EsseS: Economics, Social and Development Studies, $\quad 7(1), \quad 110-129$. https://doi.org/https://doi.org/10.2 4252/ecc.v7i1.13919

Ren, Y. (2020). Characteristics of Chinese population Development from 1949 to 2018 and Lessons Learned. China Population and Development Studies, 3(3). https://doi.org/10.1007/s42379019-00042-5

Rizal, M., \& Sholehuddin, S. (2019). Factors Affecting Labor Productivity of Small Manufacturing Industry. Jurnal Manajemen Dan Kewirausahaan, 7(1). https://doi.org/10.26905/jmdk.v7i1. 2691

Sari, R. P., Sarfiah, S. N., \& Indrawati, L. R. (2019). Analisis Pengaruh Ketimpangan Gender Terhadap Produk Domestik Regional Bruto 
(PDRB) Tahun 2011-2017 (Studi Kasus 6 Kota di Provinsi Jawa Tengah DINAMIC: Directory Journal of Economic 1.

Song, J. H., Rhee, Y., Adams, C. R., \& Azevedo, R. E. (2008). Relating Equity Investment to Human Resource Development for Business Benefits. Business Renaissance Quarterly, 3(3).

Tarmidi, D., Putri, R. K., Santoso, A. B., \& Anggapraja, I. T. (2021). Investment In Improving Human Resources In Improving Indonesia's Development Economy. Review of International Geographical Education Online, 11(6). https://doi.org/10.48047/rigeo.11.06. 4

Tejada, M., Piras, C., Flabbi, L., \& Bustelo, M. (2021). Gender gaps in Latin American labor markets: Implications from an estimated search model. Annals of Economics and Statistics, 142.

https:// doi.org/10.15609/ANNAEC ONSTAT2009.142.0111

UNDP. (2019). Human Development Report 2019: Beyond income, beyond averages, beyond today: Inequalities in human development in the 21st century. In United Nations Development Program.

Yana, F. (2019). Analisis Pengaruh Ketimpangan Gender terhadap Pertumbuhan Ekonomi di Kawasan ASEAN+4. Institut Pertanian Bogor. 